\title{
Opiate States of Memory: Receptor Mechanisms
}

\author{
L. A. Bruins Slot and F. C. Colpaert \\ Centre de Recherche Pierre Fabre, F 81106 Castres Cedex, France
}

The present studies characterized the receptor mechanisms of morphine-induced states of memory. Morphine $(5 \mathrm{mg} / \mathrm{kg})$ produced a state in which rats could learn and retrieve an operant response; retrieval was impaired, however, when the rats were tested in the normal state. Conversely, rats that were trained in the normal state failed to retrieve the response in the morphine state. In either case the mnesic state was dose dependent, commencing at morphine doses as low as $0.8 \mathrm{mg} / \mathrm{kg}$. In rats trained with $5 \mathrm{mg} / \mathrm{kg}$ of morphine, retrieval was fully adequate when tested with this same dose but not when tested with either lower or higher doses. Naloxone, but not naltrindole, antagonized the morphine-induced state; heroin and (-)cyclazocine, but not U50,488H, (+)-cyclazocine and SNC80, produced a state in which retrieval occurred at least partially. Time-effect studies in which injections were made from 0 to 240

The retrieval of an engram from memory may require that the organism be in a state that is similar to that in which the engram was initially acquired [state dependence (StD)]. Using a novel StD procedure (Colpaert, 1990), we have recently found that morphine can induce StD of milk-rewarded lever press responding in rats (Bruins Slot and Colpaert, 1999a). The latter study constitutes the first unambiguous evidence that changes in mnesic states involving morphine disable retrieval in both drug-to-saline and saline-to-drug tests of transfer. These findings are consistent, however, with earlier data (Belleville, 1964) that showed some decrement of extinction performance with morphine-to-saline changes of state but not with saline-to-morphine changes. Our findings are also consistent with the suggestion that StD is indirectly implicated in the amnestic effects of endogenous opiate peptides (Izquierdo, 1980; Izquierdo et al., 1980, 1981). The latter suggestion was based on findings that the memory impairment produced by the post-training administration of endogenous opiates can be attenuated by the administration of the same agents shortly before the retention test (Izquierdo, 1980, 1984; Izquierdo et al., 1980). It is useful to point out that the StD that morphine may induce differs from the discriminative effects that opiates also produce [in the drug discrimination (DD) paradigm] (Holtzman, 1982; Woods et al., 1982; Colpaert, 1995). Although the paradigms differ in conceptual and methodological terms (Colpaert et al., 1976), the novel StD procedure was designed to

\footnotetext{
Received July 6, 1999; accepted Sept. 16, 1999.

We gratefully acknowledge the expert technical assistance of V. Faucillon and A.-M. Ormière. We also thank Drs. J. H. Woods, W. Koek, and E. Walker for comments and suggestions. Dr. M. J. Picker kindly communicated some unpublished data.

Correspondence should be addressed to F. C. Colpaert, Centre de Recherche Pierre Fabre, 17 avenue Jean Moulin, F 81106 Castres Cedex, France. E-mail: francis.colpaert@pierre-fabre.com.

Copyright (C) 1999 Society for Neuroscience 0270-6474/99/1910520-10\$05.00/0
}

min before the sessions indicated that the retrieval in saline-tomorphine and morphine-to-saline conditions occurred along different time courses; a theory of opiate signal transduction suggests that these temporal profiles result from morphine producing two bi-directional mnesic states that may differ as much as the analgesia and hyperalgesia that morphine also induces. It appears that a particular magnitude of $\mu$ opiate receptor activation produces a state to which a memory trace can be confined in a highly selective manner. The normal and this particular morphine state are only some of the many mutually inaccessible and molecularly definable states of memory that are likely to exist, thus challenging the unitary concept of an individual organism's memory.

Key words: memory; opiates; learning; retrieval; encoding; mnesic state

render possible direct comparisons between them. As in other memory research (Morris et al., 1982), the procedure defines response latency as the dependent variable, but applies it to the completion of a fixed-ratio 10 (FR10) schedule of lever presses on a single lever. Studies comparing this single-lever StD procedure with a widely used two-lever DD procedure have indicated that the paradigms can generate different outcomes (Colpaert and Koek, 1995), corroborating other data that discriminative effects cannot account for StD (Pusakulich and Nielson, 1976; Nielson et al., 1978; Oberling et al., 1993; Kumar et al., 1994).

Further data indicate that the StD obtained with saline-tomorphine state changes occurs at a time and at doses at which morphine also produces analgesia (Bruins Slot and Colpaert, 1999a). Other evidence supports the notion that pain, or responses to nociceptive stimulations, is at least partly learned (Hebb, 1949; Nissen et al., 1951; Melzack and Scott, 1957; Merskey, 1975; Erskine et al., 1990; Morley, 1993; Porzelius, 1995). The concept being suggested by these data holds that the pain that is acquired in the course of ontogeny may be available for recall in the same but not in other states than that in which acquisition occurred (Bruins Slot and Colpaert, 1999a); biological rhythms (e.g., diurnal variations in opiate activity) may conceivably provide naturally occurring mnesic states through which StD, in normophysiological situations, may influence pain perception. The concept implies that the change of mnesic state that exogenous morphine produces may constitute a mechanism of opiate analgesia.

In the present studies, we characterized the receptor mechanisms of the morphine state on which the recall of an operant response can be rendered dependent. Specifically, experiments were conducted with various opiate receptor ligands to identify the receptor mediating morphine-induced StD. Other experiments characterized the time-response features of morphine StD 
and examined its relationship to the magnitude of receptor activation.

\section{MATERIALS AND METHODS}

Subjects. Male Sprague Dawley rats (Iffa Credo, Lyon, France) weighing $180-200 \mathrm{gm}$ on arrival were used. On arrival and for a quarantine period of 4-5 d, animals were housed five to a cage in an environmentally controlled room (ambient temperature, $21 \pm 1^{\circ} \mathrm{C}$; relative humidity, $55 \pm$ $5 \%$; $12 \mathrm{hr}$ light/dark cycle, lights on at 7 A.M.) with standard laboratory food and water freely available. The rats were transferred to the experimental room on the day before experiments began and maintained under the same environmental conditions as during quarantine. Access to food was then limited to $20 \mathrm{gm} / \mathrm{d}$, except between 5 P.M. on Friday and 2 P.M. on Sunday, when food was available freely. The protocol was in accordance with the Revised Guide for the Care and Use of Laboratory Animals (NRC 1996) and was approved by the institutional Ethical Review Committee (No. 009).

Operant apparatus and procedures. The experimental apparatus as well as the acquisition and test procedures were similar to those described elsewhere (Bruins Slot et al., 1999). Briefly, the experimental apparatus consisted of operant conditioning chambers housed in fan-ventilated, light- and sound-attenuating enclosures. Each chamber contained a house light, a lever, and a liquid dipper. Reinforcement consisted of a 4 $\mathrm{sec}$ access to the liquid dipper that contained $0.02 \mathrm{ml}$ of sweetened condensed milk.

Rats were randomly assigned to operant chambers in which they were trained to lever press for access to milk during daily 15 min sessions until they could complete an FR10 schedule of lever presses for the milk reward. Before each of these acquisition sessions, they received an injection of a dose of either a compound or physiological saline $(0.9 \%$ $\mathrm{NaCl}$ ). Training continued until animals completed the first FR10 within $120 \mathrm{sec}$ after the beginning of the session. Animals that had not reached this criterion performance after 40 sessions were discontinued. A period of $48 \mathrm{hr}$ was allowed to elapse between the criterion session (the acquisition session during which animals reached the criterion performance) and the test session. On the day of the test session, animals received a pharmacological treatment that was either the same or different from the one implemented during acquisition and were tested for the recall of the response during a single $15 \mathrm{~min}$ test session. Animals were tested only once.

Experimental design. Three series of experiments examined the dose dependency of morphine StD. In the first series ( $n=5$ per group), rats acquired the response with one of four doses of morphine injected $60 \mathrm{~min}$ before the session $(1.25,2.5,5$, or $10 \mathrm{mg} / \mathrm{kg}$, s.c. $)$ and were tested with saline [subcutaneous, $60 \mathrm{~min}$ (SC t-60)]. In the second series $(n=5 \mathrm{per}$ group), animals were trained with saline and tested with one of four doses of morphine $(1.25,2.5,5$, or $10 \mathrm{mg} / \mathrm{kg}, \mathrm{SC} \mathrm{t}-60)$. In the third series ( $n=7$ per group), animals were trained with morphine $(5 \mathrm{mg} / \mathrm{kg}$, s.c., 60 $\mathrm{min})$ and tested with one of seven doses of morphine (i.e., 0.63, 1.25, 2.5, $5,10,20$ or $40 \mathrm{mg} / \mathrm{kg}$, s.c., $60 \mathrm{~min})$. Same-state control animals were both trained and tested with saline (SC, t-60) or both trained and tested with morphine $(5 \mathrm{mg} / \mathrm{kg}$, s.c., $60 \mathrm{~min})$. Because of impaired acquisition in morphine-trained rats, additional animals were trained until $n=5$ or 7 were obtained that reached criterion and could hence be tested.

Three series of experiments examined the time dependency of morphine StD. In the first series ( $n=7$ per group), rats acquired the response with saline (SC) injected at one of nine time intervals before the session (i.e., $0,30,60,90,120,150,180,210$, or $240 \mathrm{~min}$; referred to as time of presession injection) and were tested with morphine $(5 \mathrm{mg} / \mathrm{kg}$, s.c.). The time of presession injection was always the same in acquisition and test sessions. In the second series ( $n=7$ per group), rats acquired the response with morphine $(5 \mathrm{mg} / \mathrm{kg}$, s.c.) injected at one of nine time intervals before the session (i.e., $0,30,60,90,120,150,180,210$, or 240 $\min$ ) and were tested with saline (subcutaneous) injected at the same time as during acquisition. In the third series of experiments $(n=5$ per group), rats acquired the response with morphine $(2.5 \mathrm{mg} / \mathrm{kg}$, s.c.) injected at one of nine time intervals before the session (as above) and were tested with saline (subcutaneous) injected at the same time as during acquisition. Same-state control animals were both trained and tested with saline injected subcutaneously at one of the different time intervals as specified above $(n=3$ per time interval).

Three additional series of experiments further examined the receptor mechanisms of morphine StD. In the first series, which examined pharmacological antagonism ( $n=5$ per group), animals were trained to criterion with a double treatment of either saline (SC t-60) and saline [subcutaneous, $15 \mathrm{~min}(\mathrm{SC} \mathrm{t}-15)$ ] $(\mathrm{S}+\mathrm{S})$ or $5 \mathrm{mg} / \mathrm{kg}$ morphine $(\mathrm{SC} \mathrm{t}-60)$ and saline $(\mathrm{SC} \mathrm{t}-15)(\mathrm{M}+\mathrm{S})$. These rats were then tested with a double treatment of either $5 \mathrm{mg} / \mathrm{kg}$ morphine (SC t-60) and one of the several doses of the $\mu$ antagonist naloxone (SC t-15) (M+NALX) or $5 \mathrm{mg} / \mathrm{kg}$ morphine (SC t-60) and one of the several doses of the $\delta$ antagonist naltrindole (SC t-15) (M+NALT). Same-state control animals were tested with a double treatment of either $\mathrm{S}+\mathrm{S}$ or $\mathrm{M}+\mathrm{S}$. In the second series ( $n=5$ per group), several groups of animals were trained to criterion with morphine $5 \mathrm{mg} / \mathrm{kg}$ (SC t-60) and tested with one of several doses of heroin $(0.04,0.08,0.16,0.31,0.63,1.25$, or $2.5 \mathrm{mg} / \mathrm{kg} \mathrm{SC} \mathrm{t}-60)$, (-)-cyclazocine $[0.08,0.16,0.31,0.63,1.25,2.5$, or $5 \mathrm{mg} / \mathrm{kg}$ i.p., $60 \mathrm{~min}$ (IP t-60)], (+)-cyclazocine $(0.16,0.63$, or $2.5 \mathrm{mg} / \mathrm{kg} \mathrm{IP} \mathrm{t-60),} \mathrm{U-50,488H}$ $(0.16,0.63,2.5$, or $10 \mathrm{mg} / \mathrm{kg} \mathrm{SC} \mathrm{t}-60)$, or SNC $80(2.5,10$, or $40 \mathrm{mg} / \mathrm{kg} \mathrm{IP}$ t-60). In the last series of experiments ( $n=7$ per group), animals were also trained to criterion with morphine $5 \mathrm{mg} / \mathrm{kg}$ (SC t-60) and tested with either UK 14304 (2.5 mg/kg SC t-60), chlordiazepoxide (40 mg/kg SC $\mathrm{t}-60), 8-\mathrm{OH}-\mathrm{DPAT}(0.16 \mathrm{mg} / \mathrm{kg} \mathrm{SC} \mathrm{t}-60)$, haloperidol $(0.63 \mathrm{mg} / \mathrm{kg} \mathrm{SC}$ $\mathrm{t}-60)$, ketamine (10 mg/kg SC t-60), scopolamine (2.5 mg/kg SC t-60),

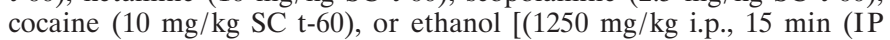
t-15)]. Same-state controls for these last two series of experiments consisted of animals trained with morphine $(5 \mathrm{mg} / \mathrm{kg}$, s.c.) and tested with $5 \mathrm{mg} / \mathrm{kg}$ morphine that was then injected by either the subcutaneous $(n=7)$ or intraperitoneal route $(n=7)$.

Drugs. The drugs used were morphine $\mathrm{HCl}$ (Coopération Pharmaceutique Française, Melun, France); naloxone $\mathrm{HCl}$, haloperidol, ketamine $\mathrm{HCl}$ (Sigma, St. Quentin, France); U-50,488H [trans-3,4-dichloro- $N$ methyl- $N$-[2-(1-pyrrolidinyl) cyclohexyl] benzeneacetamide methanesulfonate hydrate], naltrindole $\mathrm{HCl}$, chlordiazepoxide $\mathrm{HCl},( \pm)-8-\mathrm{OH}-$ DPAT hydrobromide (Research Biochemical Industries, Illkirch, France); SNC 80 [(+)-4-[( $\alpha \mathrm{R})-\alpha-((2 \mathrm{~S}, 5 \mathrm{R})-4$-allyl-2,5-dimethyl-1piperazinyl)-3-methoxybenzyl]- $N, N$-diethylbenzamide] (Tocris Cookson, Illkirch, France); (-)-cyclazocine, (+)-cyclazocine, and UK 14304 tartrate (synthesized by J. L. Maurel, Center de Recherche Pierre Fabre); heroin $\mathrm{HCl}$ (Francopia, Paris, France); (-)-scopolamine hydrobromide (Fluka, St. Quentin, France); cocaine $\mathrm{HCl}$ (Cooper, Melun, France); ethanol (Prolabo, France). (+)-,(-)-cyclazocine and SNC 80 were dissolved in a $1 \%$ Tween solution. Haloperidol was dissolved in distilled water with a drop of acetic acid after which the $\mathrm{pH}$ was adjusted to 5-7 with a solution of $4 \%$ sodium hydroxide. All other compounds were dissolved in distilled water. Doses refer to the free base weight. Treatments were administered subcutaneously or intraperitoneally, as indicated (injection volume: $1 \mathrm{ml} / 100 \mathrm{gm}$ body weight). Single treatment injections were given $60 \mathrm{~min}$ before the operant sessions; for double treatments, the two treatments were administered 60 and $15 \mathrm{~min}$ before the session.

Data analysis. The data analyzed were the number of sessions to reach criterion, and the latency to complete the first FR10 as well as the total number of lever presses that were made during the criterion and the test sessions. Sessions-to-criterion (STC) values were analyzed by means of the Kruskall-Wallis analysis of variance on ranks (Siegel and Castellan, 1988). Absolute latencies, number of lever presses, and log-transformed latency ratios (i.e., the ratio of the criterion latency to the test latency) were analyzed by means of ANOVA (Winer, 1971). Post hoc comparisons were performed using Dunnett's test for multiple comparisons. Student's $t$ test was used to analyze differences in means between two experimental groups. $\mathrm{ED}_{50}$ values and $95 \%$ confidence limits were computed according to the method of Litchfield and Wilcoxon using the PHARM/PCS program of Tallarida and Murray (1987); when less than two values between 16 and $84 \%$ were observed, 0 and/or $100 \%$ effect data points were transformed by means of Berkson's adjustment (Hubert, 1984) to enable the use of the PHARM/PCS program. Statistical significance was defined as $p<0.05$.

\section{RESULTS}

\section{Normal acquisition and same-state performance}

Previously established control data (Bruins Slot and Colpaert, 1999a) on normal acquisition ( $n=662$ rats) and same-state performance ( $n=157$ rats) have allowed us to define two criteria so that the interval data (STCs and latency ratios) can be transformed into the nominal data required to compute $\mathrm{ED}_{50}$ values. That is, $<5 \%$ of the animals that were trained in this procedure while treated with saline failed to reach criterion in $<40$ training sessions, so that STC $>40$ sessions defined the nominal criterion 
for evaluating effects on learning. Also, the latency ratio (latency found in the criterion session to the latency found in the test session) was inferior to 0.40 in $<5 \%$ of (same-state) control tests conducted in animals for which the treatment implemented during acquisition and test was the same. As a result, a ratio $<0.40$ defined the nominal criterion, indicating that failure to transfer had occurred.

\section{Drug effects on acquisition}

In the course of the dose-response experiments reported below, all 25 animals trained with saline reached criterion in $<40$ sessions. Acquisition was impaired, however, in animals that were trained with one of the different doses of morphine (i.e., 1.25-10 $\mathrm{mg} / \mathrm{kg} \mathrm{SC} \mathrm{t}-60$ ); the $\mathrm{ED}_{50}$ (and $95 \%$ confidence limits) for $>40$ STC to occur was $6.5(3.0-14) \mathrm{mg} / \mathrm{kg}$. Analysis of the STC data (Fig. $1 A$, inset) by means of a Kruskall-Wallis analysis of variance on ranks revealed a significant effect $(p<0.005)$ of morphine dose, and post hoc comparison with saline controls showed significant differences $(p<0.05)$ to occur for the 5 and $10 \mathrm{mg} / \mathrm{kg}$ doses.

\section{Morphine: dose-response studies}

Morphine-to-saline transfer tests

Animals that were trained with morphine and tested with saline showed a lack of transfer that depended on the morphine dose used in acquisition (Fig. $1 A$ ). Of the five animals per dose that were trained with $1.25,2.5,5$, or $10 \mathrm{mg} / \mathrm{kg}$ morphine and tested with saline, five, three, one, and two, respectively, showed transfer, yielding an $\mathrm{ED}_{50}$ value of 4.0 (1.9-8.6) $\mathrm{mg} / \mathrm{kg}$. A one-way ANOVA of log-transformed ratios showed a significant effect of dose $\left(F_{(4,20)}=4.5 ; p<0.01\right)$, and post hoc comparisons with saline-trained controls showed a significant difference to occur $(p<0.05)$ for the 5 and $10 \mathrm{mg} / \mathrm{kg}$ doses of morphine.

\section{Saline-to-morphine transfer tests}

Animals that were trained with saline and tested with morphine showed transfer that was dependent on the test dose of the compound (Fig. 1A). Of the five animals per group trained with saline and tested with $1.25,2.5,5$, and $10 \mathrm{mg} / \mathrm{kg} \mathrm{SC} \mathrm{t}-60$, five, four, two, and zero, respectively, showed transfer, yielding an $\mathrm{ED}_{50}$ of $4.0(2.6-6.2) \mathrm{mg} / \mathrm{kg}$. A one-way ANOVA on log-transformed latency ratios showed a significant effect of dose $\left(F_{(4,20)}=17 ; p<\right.$ $0.001)$, and post hoc comparisons with saline-tested controls showed a significant difference $(p<0.05)$ for the 5 and $10 \mathrm{mg} / \mathrm{kg}$ doses of morphine.

A comparison using the PHARM/PCS program found that the $\mathrm{ED}_{50}$ for morphine-to-saline transfer to occur was not significantly different $(p>0.05)$ from the $\mathrm{ED}_{50}$ for saline-to-morphine transfer to occur.

\section{Latency and subsequent rate}

Figure 2 provides further analyses of these morphine-to-saline and saline-to-morphine experiments. The data being considered are the absolute latency (in seconds) to complete the (first) FR10 schedule and the bar presses that thereafter were recorded during the remainder of the last training (criterion) and test sessions (subsequent response rate, in responses per second).

In criterion sessions (left panels), both latencies and subsequent response rates were similar, regardless of whether acquisition had occurred with saline or morphine.

In test sessions (right panels), latencies increased when the state that was then implemented differed from that implemented during acquisition. Latencies in changed-state conditions increased
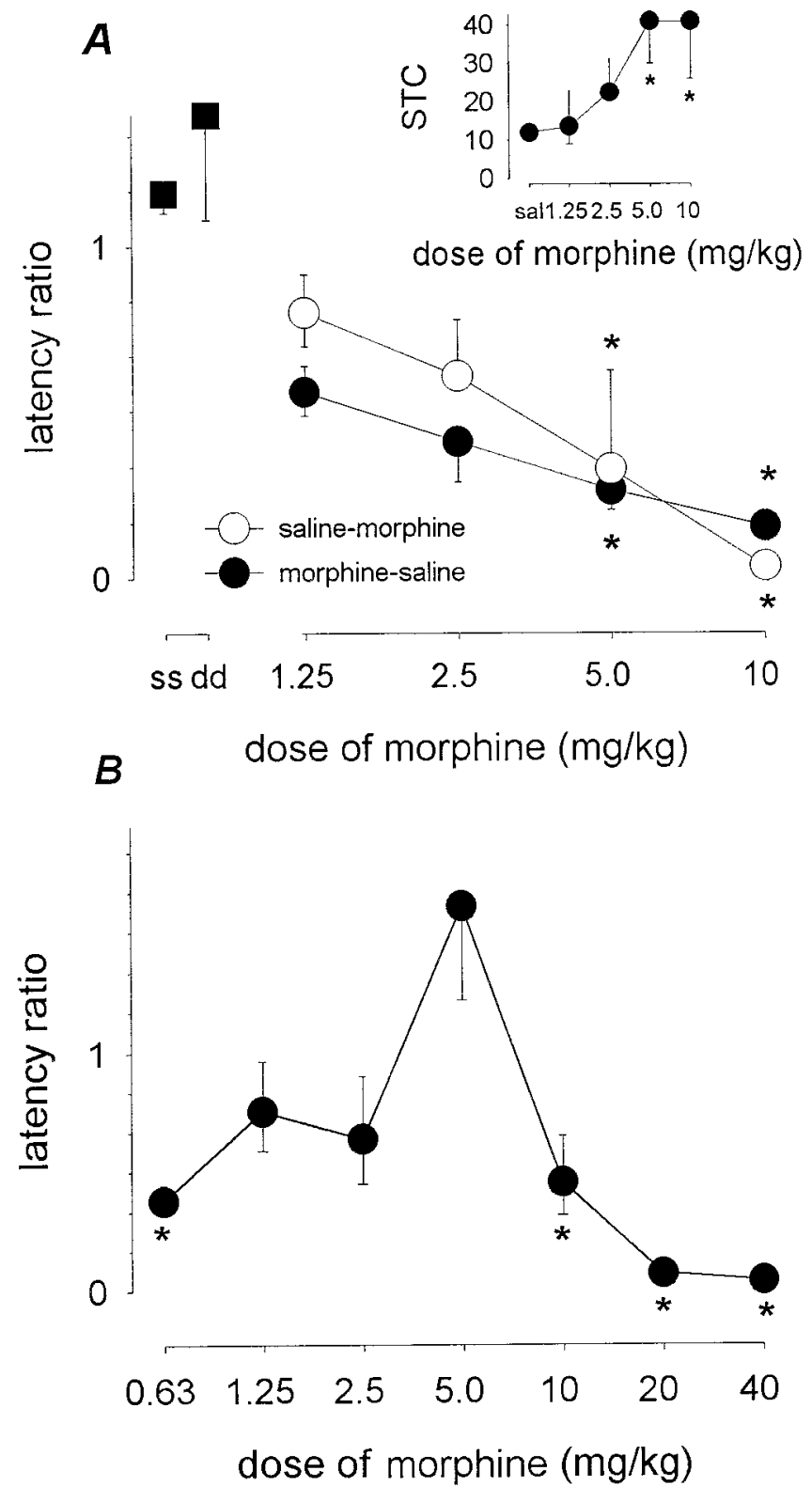

Figure 1. Morphine state dependence. In $A$, training sessions occurred $60 \mathrm{~min}$ after a subcutaneous injection of either saline or one of the different acquisition doses of morphine that are specified. Once trained, animals were given a single test session that took place 60 min after a subcutaneous injection of either saline or one of the different test doses of morphine. The vertical axis represents the log-transformed latency ratios (geometric mean $\pm 1 \mathrm{SEM})$. Same-state saline controls are represented as $s s$ whereas $d d$ represents same-state morphine controls $(5 \mathrm{mg} / \mathrm{kg})$. In the inset, the vertical axis represents the number of sessions-to-criterion (median and $25^{\text {th }}$ and $75^{\text {th }}$ percentiles). Morphine-saline and saline-morphine refer to animals trained with morphine and tested with saline and animals trained with saline and tested with morphine, respectively. Each data point is based on $n=5$. Multiple comparisons using Dunnett's method: ${ }^{*} p<0.05$ versus same-state saline controls. In $B$, training sessions occurred $60 \mathrm{~min}$ after a subcutaneous injection of $5 \mathrm{mg} / \mathrm{kg}$ morphine. Once trained, animals were given a single test session that took place $60 \mathrm{~min}$ after a subcutaneous injection of one of the different test doses of morphine. Each data point is based on $n=7$. Multiple comparisons using Dunnett's method: ${ }^{*} p<0.05$ versus same-state morphine $(5 \mathrm{mg} / \mathrm{kg})$ controls. (Where not apparent, error bars are contained by the symbol.) 

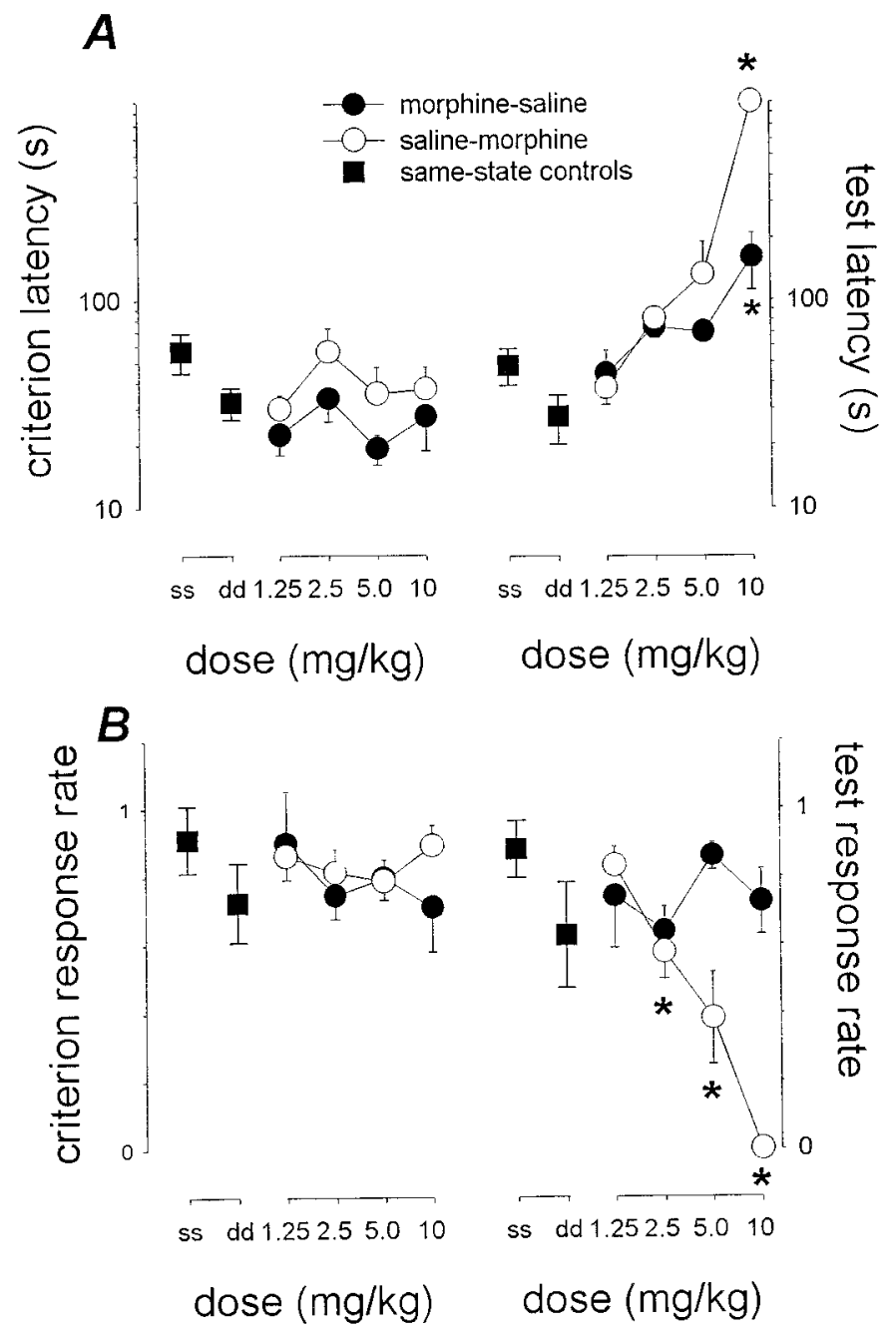

Figure 2. Latency and subsequent rate of responding in saline-tomorphine and morphine-to-saline studies of state dependence. In $A$, the ordinate represents the absolute latency to complete the (first) FR10 schedule during the last (criterion) training session (left panels) and the test session (right panel). In $B$, the ordinate represents the response rate (number of lever presses per second) that was observed after the first FR10 schedule had been completed. This rate was found as the ratio of the total number of lever presses that were made during the session minus 10 , to the total session duration (i.e., $900 \mathrm{sec}$ ) minus the latency to complete the first FR10 schedule. Same-state controls are represented as $s s$, whereas $d d$ represents same-state morphine controls $(5 \mathrm{mg} / \mathrm{kg})$. Morphine-saline and saline-morphine refer to animals trained with morphine and tested with saline, and to animals trained with saline and tested with morphine, respectively. Data points represent mean ( \pm 1 SEM) values $(n=5)$. Multiple comparisons using Dunnett's method: ${ }^{*} p<0.05$ versus same-state saline controls. (Where not apparent, error bars are contained by the symbol.)

from 48.4 to $900 \mathrm{sec}$ and from 27.4 to $161 \mathrm{sec}$ in saline-tomorphine and morphine-to-saline conditions, respectively. Oneway ANOVA of the saline-to-morphine data showed a significant effect of dose $\left(F_{(4,20)}=189 ; p<0.001\right)$. Post hoc comparisons with same-state controls found a significant effect $(p<0.05)$ at 10 $\mathrm{mg} / \mathrm{kg}$. A significant effect $\left(F_{(4,20)}=3.95 ; p<0.05\right)$ of dose also occurred with the morphine-to-saline latencies; the post hoc comparison was significant for the $10 \mathrm{mg} / \mathrm{kg}$ dose.

In addition, during test sessions, lever presses often occurred even after the latency to complete the first FR10 schedule had much increased. This completion of the schedule was rewarded, however, setting the occasion for learning to occur during the remainder of the session. The rate of this subsequent lever press behavior was fairly high in animals trained with morphine and tested with saline; ANOVA failed to reveal a significant effect of the morphine dose used in initial acquisition $\left(F_{(4,20)}=1.08 ; p=\right.$ $0.39)$. The subsequent response rate was lower, however, in saline-to-morphine conditions; the dose-effect relationship for morphine in impairing the development of this subsequent responding was similar to that in which morphine impaired initial acquisition (Fig. 1 $\mathrm{A}$, inset) in morphine-to-saline conditions. ANOVA revealed a significant effect of the morphine test dose $\left(F_{(4,20)}=18.7 ; p<0.001\right)$. Post hoc comparisons were significant $(p<0.05)$ for the $2.5,5$, and $10 \mathrm{mg} / \mathrm{kg}$ doses.

These analyses underscore the differences between the mechanisms underlying the dependent variable used to measure recall (i.e., latency) and the behavior that may occur later in the (test) session; they also indicate the ratio of latencies (Fig. $1 A$ ) to offer a more sensitive measure of retrieval than the absolute latency.

\section{Morphine-to-morphine transfer tests}

Animals that were trained with $5 \mathrm{mg} / \mathrm{kg}$ morphine and tested with one of several test doses of morphine $(0.63,1.25,2.5,5,10$, 20 , or $40 \mathrm{mg} / \mathrm{kg}$ ) showed transfer that depended on the test dose of the compound (Fig. $1 B$ ); the dose-effect relationship yielded a biphasic curve. A one-way ANOVA on log-transformed latency ratios revealed a significant effect of test dose of morphine $\left(F_{(6,42)}\right.$ $=21 ; p<0.001)$, and post hoc comparisons with animals that were both trained and tested with $5 \mathrm{mg} / \mathrm{kg}$ morphine showed that significant differences $(p<0.05)$ occurred for the $0.63,10,20$, and $40 \mathrm{mg} / \mathrm{kg}$ test doses of morphine.

\section{Morphine: time-response studies \\ Saline-to-morphine $(5 \mathrm{mg} / \mathrm{kg}$ ) transfer tests}

All of the 63 animals that acquired the response under saline reached criterion, regardless of time of presession injection. Analysis of log-transformed latency ratios in animals that were both trained and tested with saline did not reveal a significant effect of time of presession injection $\left(F_{(8,18)}=0.51, p=0.831\right)$, and these data were thus pooled in subsequent analyses (data not shown). However, animals that were trained with saline and tested with 5 $\mathrm{mg} / \mathrm{kg}$ morphine showed transfer in a manner that was dependent on the time of presession injection (Fig. 3). Analysis of logtransformed latency ratios revealed a significant effect of time of presession injection $\left(F_{(9,80)}=5.8 ; p<0.001\right)$. Post hoc comparisons with saline controls showed a significant difference $(p<$ 0.05 ) for the 30,60 , and 90 min intervals.

\section{Morphine (5 mg/kg)-to-saline transfer tests}

Acquisition was impaired in animals that were trained with morphine $(5 \mathrm{mg} / \mathrm{kg}$, s.c.) injected at one of the different time intervals before the training session $(0,30,60,90,120,150,180,210$, or 240 min). Analysis of the STC data by means of a Kruskall-Wallis ANOVA on ranks revealed a significant effect $(p<0.001)$ of time of presession injection, and post hoc comparison with saline controls showed a significant difference $(p<0.05)$ to occur for the 30,60, 90, and 120 min intervals (data not shown). Animals that were trained with morphine $(5 \mathrm{mg} / \mathrm{kg})$ and tested with saline showed transfer that was dependent on the time of presession injection (Fig. 3). Analysis of log-transformed latency ratios revealed a significant effect of time of presession injection $\left(F_{(9,80)}=\right.$ $12 ; p<0.001)$, and post hoc comparisons with saline controls indicated a significant effect $(p<0.05)$ at all time intervals, with 

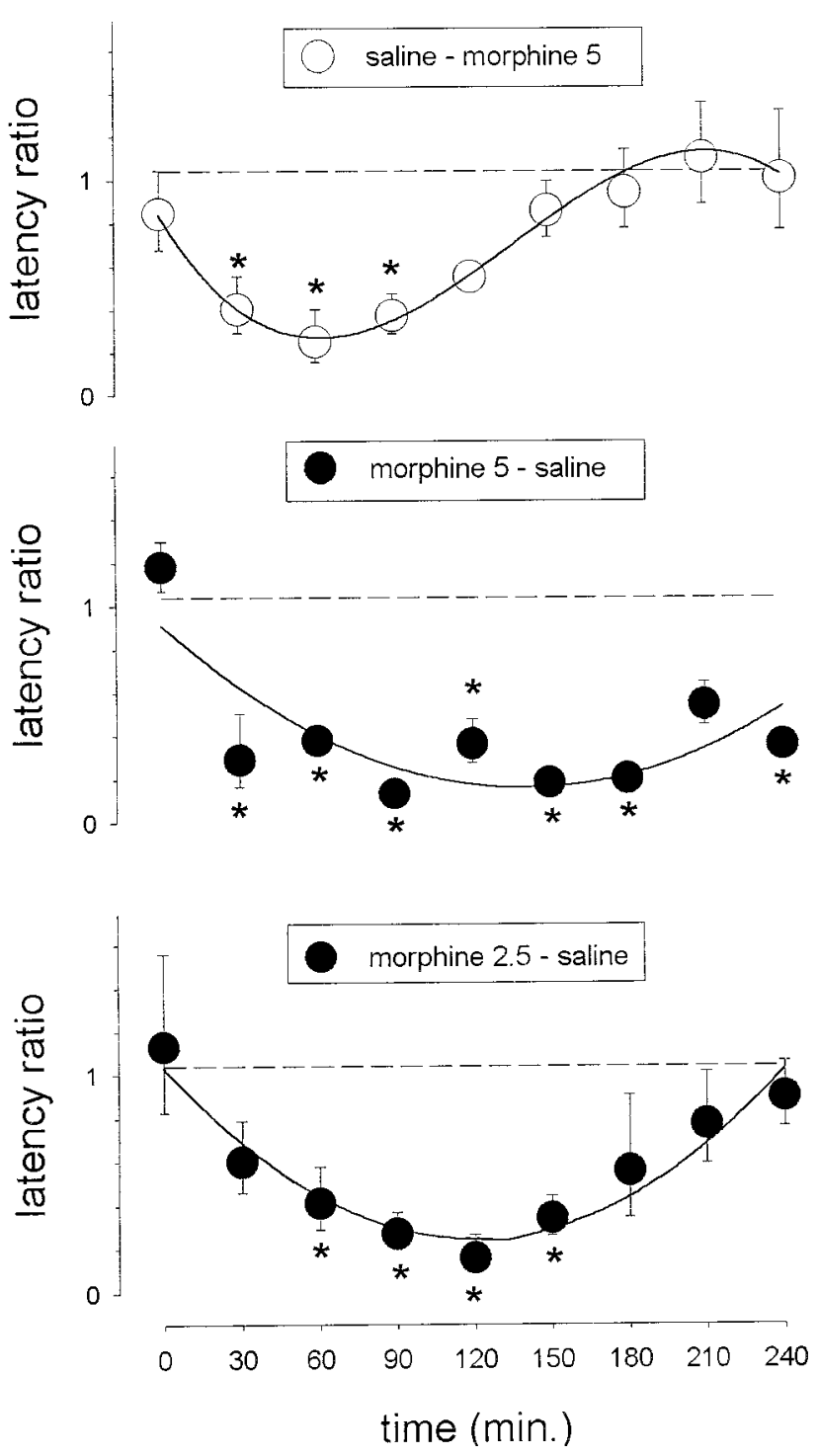

Figure 3. Time course of morphine StD. Rats received a subcutaneous injection of either morphine $(2.5 \mathrm{mg} / \mathrm{kg}, n=5$ per group; or $5 \mathrm{mg} / \mathrm{kg}, n=$ 7 per group) or saline ( $n=7$ per group) at different preacquisition session time intervals and were subsequently tested with either $5 \mathrm{mg} / \mathrm{kg}$ morphine or saline injected at the same time as during training. The vertical axis represents the log-transformed latency ratios (geometric mean \pm 1 SEM). Closed and open circles refer to animals trained with morphine and tested with saline, and to animals trained with saline and tested with morphine, respectively. The dotted line represents log-transformed latency ratios (geometric mean) of the pooled group $(n=27)$ of same-state (salinesaline) controls. Curves were fitted (Marquardt, 1963; Nash, 1979) using either quadratic or cubic polynomial equations. Multiple comparisons using Dunnett's method: ${ }^{*} p<0.05$ versus same-state saline controls. (Where not apparent, error bars are contained by the symbol.)

the exception of 0 and $210 \mathrm{~min}$. The effects found here were relatively large and generated a time-effect relationship that was flatter than that found in the saline-to-morphine time-response study. A further morphine-to-saline study was therefore conducted using a two-fold lower dose.

\section{Morphine (2.5 $\mathrm{mg} / \mathrm{kg})$-to-saline transfer tests}

Acquisition was also impaired in animals that were trained with the lower dose $(2.5 \mathrm{mg} / \mathrm{kg}$, s.c.) of morphine injected at one of the different time intervals before the training session. Analysis of the
STC data by means of a Kruskall-Wallis ANOVA on ranks revealed a significant effect $(p<0.05)$ of time of presession injection, and post hoc comparisons with saline controls showed a significant difference $(p<0.05)$ to occur for the 60 min time interval (data not shown). Animals that were trained with morphine $(2.5 \mathrm{mg} / \mathrm{kg})$ and tested with saline showed transfer that was dependent on the time of presession injection (Fig. 3). Analysis of log-transformed latency ratios revealed a significant effect of time of presession injection (ANOVA, $\mathrm{F}_{(9,62)}=6.4, p<0.001$ ). Post hoc comparisons with saline controls indicated that a significant $(p<0.05)$ effect occurred for the 60, 90, 120, and 150 min time intervals.

\section{Morphine state dependence: receptor mediation Transfer tests with opiate antagonists}

All five rats trained with a double treatment of $\mathrm{S}+\mathrm{S}$ showed complete transfer of the response when tested with $\mathrm{S}+\mathrm{S}$, whereas only two of five rats showed transfer of the response when tested with $\mathrm{M}+\mathrm{S}$. When one of the several doses $(0.01-0.63 \mathrm{mg} / \mathrm{kg}$; SC $\mathrm{t}-15)$ of naloxone was administered with $5 \mathrm{mg} / \mathrm{kg}$ morphine during test, transfer did occur in $\mathrm{S}+\mathrm{S}$-trained animals as the naloxone test dose was increased (Fig. $4 A$ ). A one-way ANOVA of log-transformed ratios revealed a significant effect of test dose of naloxone in animals trained with $\mathrm{S}+\mathrm{S}$ and tested with $\mathrm{M}+\operatorname{NALX}\left(F_{(4,20)}=3.2 ; p<0.05\right)$. Post hoc comparisons with animals trained with $\mathrm{S}+\mathrm{S}$ and tested with $\mathrm{M}+\mathrm{S}$ showed significant differences $(p<0.05)$ to occur for the $0.04,0.16$, and 0.63 test doses of naloxone. These doses thus blocked the morphine state in $\mathrm{S}+\mathrm{S}$-trained animals. Naloxone at the doses of 0.16 and $0.63 \mathrm{mg} / \mathrm{kg}$ was in itself ineffective in $\mathrm{S}+\mathrm{S}$ trained animals $\left(\mathrm{F}_{(2,12)}\right.$ $=0.41 ; p=0.675)$ (Fig. $4 A$, inset).

Rats trained with a double treatment of $\mathrm{M}+\mathrm{S}$ showed complete transfer when tested with this same treatment but not when tested with a double treatment of $\mathrm{S}+\mathrm{S}$ (Fisher's exact test; $p<0.05$ ). When one of the several doses of naloxone $(0.01-0.63 \mathrm{mg} / \mathrm{kg})$ was administered with morphine during test, transfer was progressively hampered as the naloxone test dose was increased (Fig. $4 A$ ). A one-way ANOVA of log-transformed ratios revealed a significant effect of test dose of naloxone in animals trained with $\mathrm{M}+\mathrm{S}$ and tested with $\mathrm{M}+\mathrm{NALX}\left(F_{(4,20)}=16 ; p<0.001\right)$. Post hoc comparisons with animals both trained and tested with $\mathrm{M}+\mathrm{S}$ showed a significant difference $(p<0.05)$ for all but the lowest test dose of naloxone $(0.01 \mathrm{mg} / \mathrm{kg})$; the other doses thus completely blocked the morphine state in $\mathrm{M}+\mathrm{S}$-trained animals.

When one of the several doses $(2.5-10 \mathrm{mg} / \mathrm{kg})$ of naltrindole was administered with $5 \mathrm{mg} / \mathrm{kg}$ morphine during test, transfer did occur in $\mathrm{M}+\mathrm{S}$-trained animals (Fig. 4B). Latency ratios tended to be decreased relative to controls; however, one-way ANOVA of log-transformed ratios revealed no significant effect of test dose of naltrindole $\left(F_{(3,16)}=2.0 ; p=0.155\right)$. Furthermore, compared with animals trained and tested with $\mathrm{S}+\mathrm{S}$, naltrindole $(40 \mathrm{mg} / \mathrm{kg})$ had no effect on either transfer (Fisher's exact test; $p=1.0$ ) or on log-transformed ratios (Student's $t$ test; $p=0.909$ ) in animals trained with $\mathrm{S}+\mathrm{S}$ and tested with $\mathrm{S}+\mathrm{NALT}$ (Fig. $4 B$, inset).

\section{Transfer tests with opiate agonists}

In this series of experiments, several groups of animals were trained to criterion with an acquisition treatment of morphine 5 $\mathrm{mg} / \mathrm{kg}$ (SC t-60). Comparisons were made, as appropriate, with same-state controls that consisted of animals trained with a subcutaneous injection of morphine (5 mg/kg; t-60) and tested with 

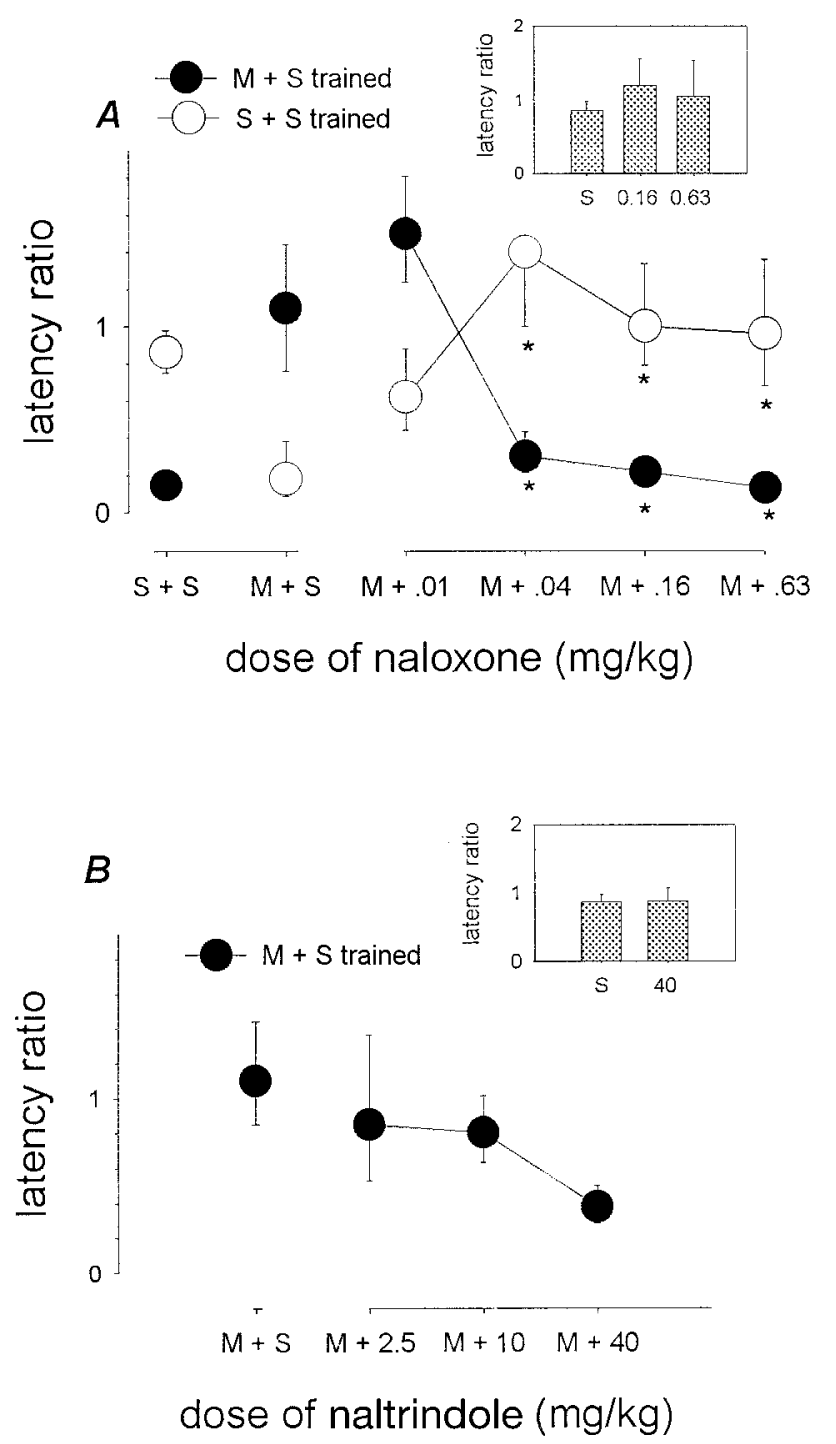

Figure 4. Receptor mediation of the morphine state: opiate antagonists. In $A$, animals were trained to criterion with either a double treatment of saline and saline $(S+S$ trained, $\bigcirc)$ or $5 \mathrm{mg} / \mathrm{kg}$ morphine and saline $(M$ $+S$ trained, 0 . Test treatments consisted of either a double treatment of saline and saline $(S+S)$ or a double treatment of $5 \mathrm{mg} / \mathrm{kg}$ morphine and one of the different doses of naloxone as specified. Inset, $\mathrm{S}+\mathrm{S}$-trained animals were tested with either $\mathrm{S}+\mathrm{S}$ or with a double treatment of saline and either 0.16 or $0.63 \mathrm{mg} / \mathrm{kg}$ of naloxone. Vertical axis represents the $\log$-transformed latency ratios (geometric mean \pm 1 SEM). Each data point is based on $n=5$. Multiple comparisons using Dunnett's method: ${ }^{*} p<0.05$ versus animals tested with a double treatment of $\mathrm{M}+\mathrm{S}$. In $B$, animals were trained with a double treatment of $5 \mathrm{mg} / \mathrm{kg}$ morphine and saline $(M+S)$ and tested with a double treatment of $5 \mathrm{mg} / \mathrm{kg}$ morphine and one of the different doses of naltrindole as specified. Inset, $\mathrm{S}+$ S-trained animals were tested with either $\mathrm{S}+\mathrm{S}$ or with saline and 40 $\mathrm{mg} / \mathrm{kg}$ naltrindole. Multiple comparisons using Dunnett's method: * $p<$ 0.05 versus animals trained and tested with a double treatment of $\mathrm{M}+\mathrm{S}$. (Where not apparent, error bars are contained by the symbol.).

either a subcutaneous or intraperitoneal injection of morphine (5 $\mathrm{mg} / \mathrm{kg}$; $\mathrm{t}-60)$.

A one-way ANOVA on log-transformed ratios (Fig. 5) in animals tested with one of the several doses of heroin (0.04-2.5 $\mathrm{mg} / \mathrm{kg})$ revealed a significant effect of heroin dose $\left(F_{(7,32)}=10\right.$; $p<0.001)$. Post hoc comparisons with same-state morphine controls (trained and tested with a subcutaneous injection)

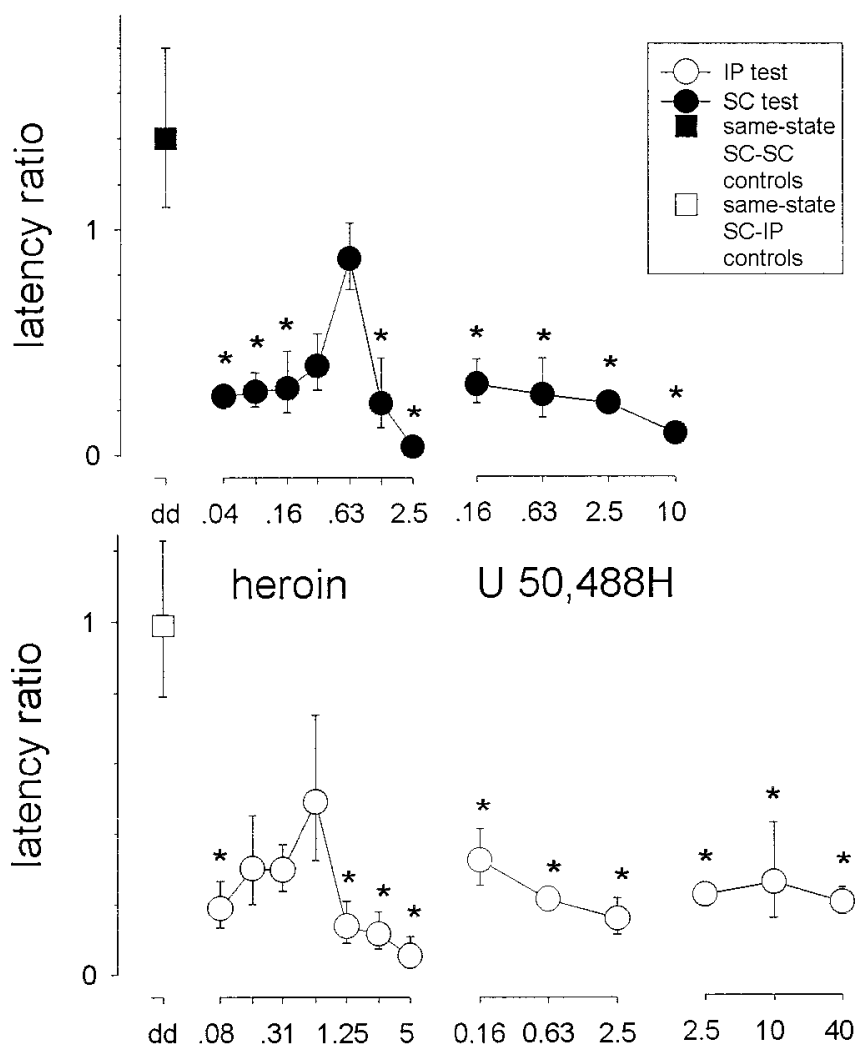

(-)-cyclazocine (+)-cyclazocine SNC 80

Figure 5. Receptor mediation of the morphine state: opiate agonists. Training sessions occurred $60 \mathrm{~min}$ after a subcutaneous injection of 5 $\mathrm{mg} / \mathrm{kg}$ morphine. Once trained, animals were given a single test session that took place $60 \mathrm{~min}$ after a subcutaneous or intraperitoneal injection of one of the different test doses of heroin, (-)-cyclazocine, (+)cyclazocine, U,50488H, or SNC 80. The vertical axis represents the log-transformed latency ratios (geometric mean \pm 1 SEM). Dotted lines represent the appropriate same-state controls consisting of animals both trained and tested with $5 \mathrm{mg} / \mathrm{kg}$ morphine. Each data point is based on $n=5$. Multiple comparisons using Dunnett's method: ${ }^{*} p<0.05$ versus appropriate same-state morphine controls. (Where not apparent, error bars are contained by the symbol.)

showed that a significant difference occurred $(p<0.05)$ for all doses except 0.31 and $0.63 \mathrm{mg} / \mathrm{kg}$. The dose-effect relationship assumed a biphasic shape with an $\mathrm{ED}_{50}$ substitution dose of 0.18 (0.074-0.42) $\mathrm{mg} / \mathrm{kg}$ for the ascending limb of the curve.

In animals tested with one of the several doses (i.e., 0.08-5 $\mathrm{mg} / \mathrm{kg}$ ) of (-)-cyclazocine, a one-way ANOVA of logtransformed ratios revealed a significant effect of dose $\left(F_{(7,32)}=\right.$ 4.6; $p<0.001)$. Post hoc comparisons with same-state morphine controls (trained with a subcutaneous injection and tested with an intraperitoneal injection) showed that a significant difference occurred $(p<0.05)$ for the $0.08,1.25,2.5$, and $5 \mathrm{mg} / \mathrm{kg}$ doses of $(-)$-cyclazocine. Because initial tests with doses differing fourfold found some degree of transfer, both (-)-cyclazocine and heroin were eventually tested with doses differing only twofold. Despite this higher resolution, (-)-cyclazocine fell well short of substituting fully for morphine: the mean latency ratio even at $0.63 \mathrm{mg} / \mathrm{kg}$ was only 0.49 .

Several doses $(0.16-2.5 \mathrm{mg} / \mathrm{kg})$ of (+)-cyclazocine were also tested in animals trained with $5 \mathrm{mg} / \mathrm{kg}$ morphine. A one-way ANOVA of log-transformed ratios revealed a significant effect of 
Table 1. Results of transfer tests with non-opiate compounds

\begin{tabular}{lllr}
$\begin{array}{l}\text { Acquisition } \\
\text { treatment }\end{array}$ & Test treatment & Latency ratio & $\%$ transfer \\
\hline Morphine (5) & Morphine (5) & $1.1 \quad(0.94-1.2)$ & 100 \\
Morphine (5) & UK 14304 (2.5) & $0.030(0.024-0.037)^{*}$ & 0 \\
Morphine (5) & Chlordiazepoxide (40) & $0.18(0.12-0.27)^{*}$ & 28 \\
Morphine (5) & $( \pm)-8-O H-D P A T ~(0.16)$ & $0.22(0.18-0.25)^{*}$ & 0 \\
Morphine (5) & Haloperidol (0.63) & $0.083(0.056-0.13)^{*}$ & 0 \\
Morphine (5) & Ketamine (10) & $0.24(0.20-0.28)^{*}$ & 14 \\
Morphine (5) & Scopolamine (2.5) & $0.077(0.063-0.095)^{*}$ & 0 \\
Morphine (5) & Cocaine (10) & $0.15(0.11-0.21)^{*}$ & 14 \\
Morphine (5) & Ethanol (1250) & $0.048(0.029-0.080)^{*}$ & 0
\end{tabular}

Rats were trained to complete a fixed-ratio 10 (FR10) schedule of lever press responses for sweetened milk reward within $120 \mathrm{sec}$ after the beginning of a $15 \mathrm{~min}$ session. Training sessions occurred $60 \mathrm{~min}$ after a subcutaneous injection of $5 \mathrm{mg} / \mathrm{kg}$ morphine. Once trained, rats were given one test session that took place $60 \mathrm{~min}$ after a subcutaneous injection of one of the different test treatments (each in $n=7$ animals; dose in parentheses). Latency ratio is the ratio of the latency found in the criterion session to the latency found in the test session, expressed as the geometric mean ( \pm 1 SEM). \% transfer is the percentage of animals tested that had a ratio latency $>0.4$. Multiple comparisons using Dunnett's method: ${ }^{*} p<0.05$ compared with same-state morphine $(5 \mathrm{mg} / \mathrm{kg})$ controls.

dose of the compound $\left(F_{(3,16)}=12 ; p<0.001\right)$. Post hoc comparisons with same-state morphine controls (trained with a subcutaneous injection and tested with an intraperitoneal injection) showed that significant differences occurred $(p<0.05)$ for all three doses of the compound.

In animals trained with $5 \mathrm{mg} / \mathrm{kg}$ morphine and tested with $\mathrm{U} 50,488 \mathrm{H}$, there was a significant effect of test dose (0.16-5 $\mathrm{mg} / \mathrm{kg})$ on log-transformed ratios $\left(F_{(4,20)}=9.3 ; p<0.001\right)$. Post hoc comparisons with same-state morphine controls (trained and tested with a subcutaneous injection) showed that differences occurred $(p<0.05)$ for all four doses of the compound.

A one-way ANOVA of log-transformed ratios in animals trained with $5 \mathrm{mg} / \mathrm{kg}$ morphine and tested with different doses $(2.5-40 \mathrm{mg} / \mathrm{kg})$ of SNC 80 revealed a significant effect of dose of SNC $80\left(\mathrm{~F}_{(3,16)}=6.2 ; p<0.005\right)$. Post hoc comparisons with animals both trained (subcutaneous) and tested (intraperitoneal) with morphine showed that all doses produced significant differences $(p<0.05)$.

\section{Transfer tests with non-opiate agonists}

The following non-opiate compounds (injected subcutaneously, $\mathrm{t}-60 \mathrm{~min}$; dose in milligrams per kilograms in parentheses) failed to induce transfer (Table 1$)$ in all rats $(n=7$ per test compound) trained with $5 \mathrm{mg} / \mathrm{kg}$ morphine: UK 14304 (2.5), ( \pm )-8-OHDPAT (0.16), haloperidol (0.63), scopolamine (2.5), and ethanol (1250). In animals tested with chlordiazepoxide (40), two of seven animals showed transfer of the response, and in animals tested with ketamine (10) and cocaine (10), one of seven animals showed transfer of the response. A one-way ANOVA on logtransformed ratios revealed a significant effect of treatment $\left(F_{(8,54)}=11 ; p<0.001\right)$, and post hoc comparisons with animals trained and tested with morphine $(5 \mathrm{mg} / \mathrm{kg})$ showed a significant difference $(p<0.05)$ for all of the different test treatments.

\section{DISCUSSION}

The present results confirm earlier data (Bruins Slot and Colpaert, 1999a) indicating that morphine produces StD with both morphine-to-saline and saline-to-morphine changes of mnesic state. That is, in animals trained with morphine, recall of the response occurred readily when the animals were tested in the same morphine-induced state, but response was impaired when animals were tested in the non-drug normal state. Also, animals that had learned in the normal state did recall in this same state but not in the morphine state. This StD was dose dependent and occurred at low doses $\left(\mathrm{ED}_{50} 4.0 \mathrm{mg} / \mathrm{kg}\right.$ in either case). Graphic extrapolation of the data in Figure $1 A$ indicates that it commences from a morphine dose of $\sim 0.8 \mathrm{mg} / \mathrm{kg}$ onward.

It may be argued that the failure to recall in the saline-to-drug tests is caused by morphine producing rate depression rather than a mnesic deficit. However, rate depression constitutes an observation rather than a mechanism (Colpaert, 1990) and cannot account for the failure to recall that was observed in the drug-tosaline tests. Detailed analysis (Fig. 2) showed that recall in test sessions did not co-vary with response rate and was in accordance with earlier findings (Colpaert, 1990) that in saline-trained animals, haloperidol severely depressed the response rate and did not affect the latency measure of recall. Note that in animals that acquired the response with morphine, the failure to respond when tested with saline is compatible with dependence, and StD in fact constitutes a proposed mechanism of opiate dependence (Colpaert, 1990, 1996). Morphine did impair acquisition, however, both in initial training (Fig. $1 A$, inset) and during test sessions (Fig. 2). This impairment may not be attributable to rate depression either. Cocaine in similar conditions (Colpaert, 1990) severely impaired learning during initial training but exerted no significant effects on rate in saline-trained rats. These and further observations cited below demonstrate that the latency measure of recall in this paradigm appears to be dependent (Colpaert, 1990) from the unspecific effects that various agents are often believed to exert on rates of behavior.

Interestingly, a study of dose-to-dose transfer (Fig. $1 B$ ) in rats trained with $5 \mathrm{mg} / \mathrm{kg}$ of morphine revealed that transfer occurred adequately when animals were tested with $5 \mathrm{mg} / \mathrm{kg}$ but not with test doses that were either lower or higher. A similarly bell-shaped dose-response curve was also obtained in transfer tests with heroin and (-)-cyclazocine (Fig. 5). These data suggest that the mnesic state produced by $5 \mathrm{mg} / \mathrm{kg}$ of morphine is specific to a particular magnitude of opiate receptor activation: both lower and higher doses generate different magnitudes. Another conceivable explanation is that the ascending and descending limbs of the dose-response curve involve different receptor populations, but data discussed below fail to support this possibility. The tolerance that is generally believed to develop to opiates [howev- 
er, see Colpaert $(1995,1996)]$ also may not account for these findings. Its supposed development, in the present experiments, to the $5 \mathrm{mg} / \mathrm{kg}$ acquisition dose of morphine fails to explain why this dose remained necessary for recall to occur, whereas lower doses and saline failed to do so (Figs. 1, 4).

The time course of morphine StD was investigated in rats that were trained in the normal state and tested at different time intervals after the injection of $5 \mathrm{mg} / \mathrm{kg}$ of morphine. The data (Fig. 3) show that morphine's effect grows orderly from time 0 onward, reaches a peak after $60 \mathrm{~min}$, and then decays and disappears after $3 \mathrm{hr}$. The data confirm earlier findings (Bruins Slot and Colpaert, 1999a) demonstrating that a peak occurs at $60 \mathrm{~min}$ under similar conditions. This time course closely parallels that of the concentration of morphine found using in vivo microdialysis of cortical extracellular fluid after a subcutaneous injection of morphine in the rat (Barjavel et al., 1995). The time course also parallels that of the analgesic effects of subcutaneous morphine in the rat (Janssen et al., 1963; van den Hoogen and Colpaert, 1987; Bruins Slot and Colpaert, 1999a). The time course of morphine StD as assessed with saline-to-drug state changes thus appears to reflect the dynamics of opiate receptor activation in the CNS. However, a different time course was obtained in studies in which acquisition occurred at different time intervals after morphine injection and in which tests were then conducted in the normal state (Fig. 3). In these studies using the same $5 \mathrm{mg} / \mathrm{kg}$ dose, StD also grew from time 0 onward, but seemed to reach peak at some time later than 60 min after injection; the effect remained marked until $4 \mathrm{hr}$ after injection. Morphine-to-saline experiments using a lower, $2.5 \mathrm{mg} / \mathrm{kg}$ dose yielded less powerful effects but again with a peak that clearly occurred at a time later than $60 \mathrm{~min}$. Thus, unlike the case with saline-to-drug transfer, the time course with drug-to-saline transfer did not parallel the dynamics of opiate receptor activation. The effect reached peak at a later time, lasted longer, and generated a flatter time-effect curve.

A theory of signal transduction (Colpaert, 1978, 1996) specifies that any neuronal input, such as opiate receptor activation, is evaluated by its departure from mean past activity. This mechanism makes the input generate two effects that are paradoxical, or bi-directional; these are referred to as first and second order effects, respectively. This signal transduction theory uniquely accounts for (Bruins Slot and Colpaert, 1999b) the paradoxical effects that opiates are known to produce (Colpaert, 1996). For example, opiate receptor activation both inhibits and paradoxically stimulates adenylyl cyclase activity (Avidor-Reiss et al., 1995) and cAMP formation (Wang and Gintzler, 1994) and produces both analgesia and hyperalgesia (Kayan et al., 1971; Tilson et al., 1973; Colpaert, 1996). In the recent research cited above (Bruins Slot and Colpaert, 1999b), numerical simulations based on this theory adequately predicted the time courses of the (first order) analgesia and (second order) hyperalgesia that 5 $\mathrm{mg} / \mathrm{kg}$ of morphine produces in the rat tail-flick procedure. The two time courses differed. The first order effect reached peak at $60 \mathrm{~min}$ and paralleled receptor activation, whereas the second order effect reached peak at $120 \mathrm{~min}$. Also, the second order effect outlasted receptor activation and yielded a flatter timeeffect curve. Thus, the temporal dynamics of the mnesic states studied here (Fig. 3) with saline-to-morphine and morphine-tosaline state changes would correspond to those of first and second order effects, respectively. One implication would be that morphine produces two, rather than one, mnesic states so that both differ from the normal state. The two mnesic states also differ from each other, and do so as much as analgesia and hyperalgesia are different. Although it is difficult at this point to further identify these two mnesic states, it is interesting that another instance of opiate paradoxes is the production, by opiates, of both euphoria and dysphoria (Colpaert, 1996). Memory function has rarely been studied under these particular conditions, but has been examined in other conditions that are also characterized by different moods. That is, in humans, similar-affect (moodcongruent) items are better learned and remembered than items that are not (Bower, 1981; Clark and Teasdale, 1982; Blaney, 1986; Kenealy, 1997), and the recall of unpleasant items in depressed patients appears to be better than that of other items (Willner, 1985; Dalgleish and Watts, 1990).

Further experiments examined the receptor mechanisms of morphine-induced StD. Previous work found that CNS agents other than morphine also produce StD in the conditions used here. However, the benzodiazepine receptor agonist chlordiazepoxide (Colpaert, 1990), the noncompetitive NMDA antagonist ketamine (Jackson et al., 1992), and the indirect GABA receptor agonist ethanol (Bruins Slot et al., 1999) failed (Table 1) to substitute for morphine (i.e., if anything, these compounds produced mnesic states different from those produced by morphine). Other CNS compounds failing to substitute for morphine were the $\alpha_{2}$ agonist UK 14304, the 5-HT $\mathrm{HT}_{1 \mathrm{~A}}$ agonist 8 -OH-DPAT, the $\mathrm{D}_{2}$ antagonist haloperidol, the muscarinic receptor antagonist scopolamine, and the DA reuptake inhibitor cocaine (Table 1). Neither SNC 80 nor U,50488H, agonists at $\delta$ (Calderon et al., 1994) and $\kappa$ receptors (Von Voigtlander et al., 1983), respectively, could substitute for morphine (Fig. 5). As with saline, the disruption of transfer observed with the 0.16 and $0.63 \mathrm{mg} / \mathrm{kg}$ doses of $\mathrm{U}, 50488-\mathrm{H}$ is interesting in that these doses do not produce the presumably nonspecific disruptive effects on behavior that compounds can arguably generate. U,50488-H decreases rates of schedule-controlled behavior in rats at $\mathrm{ED}_{50}$ values ranging from 2.6 to $3.8 \mathrm{mg} / \mathrm{kg}$ (Picker et al., 1996; Pitts et al., 1996a,b). The $(+)$-isomer of cyclazocine, possessing affinity for $\sigma$ and PCP but not for $\mu$ opiate receptors (Zukin et al., 1984), also failed to substitute for morphine. In fact, $(-)$-cyclazocine, and to a greater extent heroin, were the only compounds substituting at least partially for morphine, likely reflecting the different magnitudes of activation that these ligands produce at the $\mu$ opiate receptor (Traynor and Nahorski, 1995; Emmerson et al., 1996; Traynor, 1996). The partial substitution obtained with $0.16-0.63 \mathrm{mg} / \mathrm{kg}$ doses of $(-)$-cyclazocine also is of particular interest, because at $0.46-1.1 \mathrm{mg} / \mathrm{kg}\left(\mathrm{ED}_{50}\right)$ doses, this compound decreases rates of behavior in other conditions [M. J. Picker, personal communication; see also Picker et al. (1992)]. Finally, low doses of the $\mu$ antagonist naloxone (Dhawan et al., 1996) but not of the $\delta$ antagonist naltrindole (Portoghese et al., 1988) antagonized the morphine state, both in saline- and in morphine-trained animals (Fig. 4). Collectively, these findings suggest that morphine StD is characterized by features that are highly specific to $\mu$ opiate receptors (Woods et al., 1982).

The present findings also add to the notion (see introductory remarks) that the StD and DD paradigms concern distinct neurobiological phenomena. First, doses of morphine $>5 \mathrm{mg} / \mathrm{kg}$ in this StD paradigm consistently failed to produce transfer in rats that had acquired the response with $5 \mathrm{mg} / \mathrm{kg}$ (Fig. 1). This finding is in stark contrast to DD studies consistently showing that 10 $\mathrm{mg} / \mathrm{kg}$ of morphine produce complete generalization in rats that discriminate between $5.6 \mathrm{mg} / \mathrm{kg}$ morphine and saline (Shannon and Holtzman, 1979; Young et al., 1992; Powell et al., 1994). Greater-than-training doses also consistently produce complete 
generalization in rats discriminating between 3.0 or $10 \mathrm{mg} / \mathrm{kg}$ doses of morphine and saline (Negus et al., 1990; Picker et al., 1990; Ohno et al., 1992; Morgan and Picker, 1996). Second, the StD paradigm generated two different time-effect curves (Fig. 3). This finding again contrasts with DD studies using opiate training drugs in rats showing that these generate only one time-effect curve (Shannon and Holtzman, 1976; Colpaert et al., 1978; Teal and Holtzman, 1980; Locke and Holtzman, 1985; Picker et al., 1990).

In conclusion, morphine produces a state of memory so that a response that was acquired in the morphine state cannot be recalled in the normal state, Also, a response that was acquired in the normal state cannot be recalled in the morphine state. Studies using $5 \mathrm{mg} / \mathrm{kg}$ show that the morphine StD is highly specific; the state could only be produced by ligands for $\mu$ opiate receptors, but not by ligands for other opiate or non-opiate signaling systems, and required that brain $\mu$ opiate receptors be activated to a particular magnitude. Both lower- and higher-magnitude activations failed to reproduce the state. The $\mu$ opiate receptor activation produced by $5 \mathrm{mg} / \mathrm{kg}$ of morphine in the rat in fact appears to generate two mnesic states that proceed along different time courses and are likely to be just as heterogeneous as analgesia and pain, as well as the many other bi-directional effects that opiates produce. As discussed elsewhere (Colpaert, 1996), the operation of opiate StD throughout ontogeny would allow an organism to vastly multiply the capacity that it has to learn and deploy but also to constrain the results of experience. Further research implementing other magnitudes of activation of $\mu$ receptors (Colpaert, 1990) and evidence involving other receptors are uncovering the existence of large numbers of different mnesic states and challenge the commonly held, unitary concept of an individual organism's memory.

\section{REFERENCES}

Avidor-Reiss T, Bayewitch M, Levy R, Matus-Leibovitch N, Nevo I, Vogel Z (1995) Adenylyl cyclase supersensitisation in $\mu$-opioid receptor-transfected Chinese hamster ovary cells following chronic opioid treatment. J Biol Chem 270:29732-29738.

Barjavel MJ, Scherrman JM, Bhargava HN (1995) Relationship between morphine and its metabolites in the rat: a microdialysis study. $\mathrm{Br} \mathrm{J}$ Pharmacol 116:3205-3210.

Belleville RE (1964) Control of behavior by drug-produced internal stimuli. Psychopharmacologia 5:95-105.

Blaney PH (1986) Affect and memory: a review. Psychol Bull 99:229-246.

Bower GH (1981) Mood and memory. Am Psychol 36:129-148.

Bruins Slot LA, Colpaert FC (1999a) Recall rendered dependent on an opiate state. Behav Neurosci 113:337-344.

Bruins Slot LA, Colpaert FC (1999b) Experimental realization of a signal transduction mechanism. J Theor Biol 200:39-48.

Bruins Slot LA, Koek W, Colpaert FC (1999) Ethanol state dependence involving a lever press response requirement in rats. Behav Pharmacol 10:229-233.

Calderon SN, Rothman RB, Porreca F, Flippen-Anderson JL, McNutt RW, Xu H, Smith LE, Bilsky EJ, Davis P, Rice KC (1994) Probes for narcotic receptor mediated phenomena. 19. Synthesis of $(+)-4-$ [(aR)-a(2S,5R)-4-allyl-2,5-dimethyl-1-piperazinyl)-3-methoxybenzyl]-N, $\mathrm{N}$-diethylbenzamide (SNC80): a highly selective, nonpeptide delta opioid receptor agonist. J Med Chem 37:2125-2128.

Clark DM, Teasdale JD (1982) Diurnal variations in clinical depression and accessibility of memories of positive and negative experiences. $\mathrm{J}$ Abnorm Psychol 91:87-95.

Colpaert FC (1978) Narcotic cue, narcotic analgesia, and the tolerance problem: the regulation of sensitivity to drug cues and to pain by an internal cue processing model. In: Stimulus properties of drugs: ten years of progress (Colpaert FC, Rosecrans J, eds), pp 301-321. Amsterdam: Elsevier/North Holland Biomedical.
Colpaert FC (1990) Amnesic trace locked into the benzodiazepine state of memory. Psychopharmacology (Berl) 102:28-36.

Colpaert FC (1995) Drug discrimination: no evidence for tolerance to opiates. Pharmacol Rev 47:605-629.

Colpaert FC (1996) System theory of pain and of opiate analgesia: no tolerance to opiates. Pharmacol Rev 48:355-402.

Colpaert FC, Koek W (1995) Empirical evidence that the state dependence and drug discrimination paradigms can generate different outcomes. Psychopharmacology (Berl) 120:272-279.

Colpaert FC, Niemegeers CJE, Janssen PAJ (1976) Theoretical and methodological considerations on drug discrimination learning. Psychopharmacology (Berl) 46:169-177.

Colpaert FC, Niemegeers CJE, Janssen PAJ (1978) Narcotic cueing and analgesic activity of narcotic analgesics: associative and dissociative characteristics. Psychopharmacology (Berl) 57:21-26.

Dalgleish T, Watts FN (1990) Biases of attention and memory in disorders of anxiety and depression. Clin Psychol Rev 10:589-604.

Dhawan BN, Cesselin F, Raghubir R, Reisine T, Bradley PB, Portoghese PS, Hamon M (1996) International Union of Pharmacology. XII. Classification of opioid receptors. Pharmacol Rev 48:567-592.

Emmerson PJ, Clark MJ, Mansour A, Akil H, Woods JH, Medzihradsky F (1996) Characterization of opioid agonist efficacy in $\mathrm{C}_{6}$ glioma cell line expressing the $\mu$ opioid receptor. J Pharmacol Exp Ther 278:1121-1127.

Erskine A, Morley S, Pearce S (1990) Memory for pain: a review. Pain 41:255-265.

Hebb DO (1949) The organisation of behaviour. New York: Wiley.

Holtzman SG (1982) Stimulus properties of opioids with mixed agonist and antagonist activity. Fed Proc 41:2328-2332.

Hubert JJ (1984) Bioassay. Dubuque, IA: Kendall/Hunt.

Izquierdo I (1980) Effect of $\beta$-endorphin and naloxone on acquisition, memory, and retrieval of shuttle avoidance and habituation learning in rats. Psychopharmacology (Berl) 69:111-115.

Izquierdo I (1984) Endogenous state dependency: memory depends on the relation between the neurohumoral and hormonal states present after training and at the time of testing. In: Neurobiology of learning and memory (Lynch G, McGaugh JL, eds), pp 333-358. New York: Guilford Press.

Izquierdo I, Souza DO, Carrasco MA, Dias RD, Perry ML, Eisinger S, Elisabetsky E, Vendite DA (1980) Beta-endorphin causes retrograde amnesia and is released from the rat brain by various forms of training and stimulation. Psychopharmacology (Berl) 70:173-177.

Izquierdo I, Perry ML, Dias RD, Souza DO, Elisabetsky E, Carrasco MA, Orsingher OA, Netto CA (1981) Endogenous opioids, memory modulation and state dependency. In: Endogenous peptides and learning and memory processes (Martinez JL, Jensen RA, Messing RB, Rigter H, McGaugh JL, eds), pp 269-290. New York: Academic.

Jackson A, Koek W, Colpaert FC (1992) NMDA antagonists make learning and recall state-dependent. Behav Pharmacol 3:415-421.

Janssen PA, Niemegeers CJE, Dony JGH (1963) The inhibitory effect of fentanyl and other morphine-like analgesics on the warm water induced tail withdrawal reflex in rats. Arzneimittelforschung 13:502-507.

Kayan S, Woods LA, Mitchell CL (1971) Morphine-induced hyperalgesia in rats tested on the hot plate. J Pharmacol Exp Ther 177:509-513.

Kenealy PM (1997) Mood-state-dependent retrieval: the effects of induced mood on memory reconsidered. Q J Exp Psychol 50:290-317.

Kumar KB, Ramalingam S, Sudhakar Karanth K (1994) Phenotoin and phenobarbital: a comparison of their state-dependent effects. Pharmacol Biochem Behav 47:951-956.

Locke KW, Holtzman SG (1985) Characterization of the discriminative stimulus effects of centrally administered morphine in the rat. Psychopharmacology (Berl) 87:1-6.

Marquardt DW (1963) An algorithm for least squares estimation of parameters. J Soc Indust Appl Math 11:431-441.

Melzack R, Scott TH (1957) The effects of early experience on the responses to pain. J Comp Physiol Psychol 50:155-161.

Merskey H (1975) Pain, learning and memory. J Psychosom Res 19:319-324.

Morgan D, Picker MJ (1996) Contribution of individual differences to discriminative stimulus, antinociceptive and rate-decreasing effects of opioids: importance of the drug's relative intrinsic activity at the $m u$ receptor. Behav Pharmacol 6:261-275.

Morley S (1993) Vivid memory for "everyday" pains. Pain 55:55-62.

Morris RGM, Garrud P, Rawlins JNP, O'Keefe J (1982) Place navigation impaired in rats with hippocampal lesions. Nature 297:681-683. 
Nash JC (1979) Compact numerical methods for computers: linear algebra and function minimization. New York: Wiley.

Negus SS, Picker MJ, Dykstra LA (1990) Interactions between mu and kappa opioid agonists in the rat drug discrimination procedure. Psychopharmacology (Berl) 105:465-473.

Nielson HC, Dewitt JR, Gill JH (1978) Some failures of the drug discrimination hypothesis of state-dependent learning. In: Stimulus properties of drugs: ten years of progress (Colpaert FC, Rosecrans JA, eds), pp 423-443. Amsterdam: Elsevier/North-Holland Biomedical.

Nissen KW, Chow RL, Semmes J (1951) Effects of restricted opportunity for tactual, kinesthetic and manipulative experience on the behaviour of a chimpanzee. Am J Psychol 64:485-507.

Oberling P, Rocha B, Di Scala G, Sandner G (1993) Evidence for statedependent retrieval in conditioned place aversion. Behav Neurol Biol 60:27-32.

Ohno M, Yamamoto T, Ueki S (1992) Analgesic and discriminative stimulus properties ofU-62,066 E, the selective kappa-opioid receptor agonist, in the rat. Psychopharmacology (Berl) 106:31-38.

Picker MJ, Doty P, Negus SS, Mattox SR, Dykstra LA (1990) Discriminative stimulus properties of U50,488 and morphine: effects of training dose on stimulus substitution patterns produced by mu and kappa opioid agonists. J Pharmacol Exp Ther 254:13-22.

Picker MJ, Craft RM, Negus SS, Powell KR, Mattox SR, Jones SR, Hargrove BK, Dykstra LA (1992) Intermediate efficacy mu opioids: examination of their morphine-like stimulus effects and response ratedecreasing effects in morphine-tolerant rats. J Pharmacol Exp Ther 263:668-681.

Picker MJ, Mathewson C, Allen RM (1996) Opioids and rate of positively reinforced behavior. III. Antagonism by the long-lasting kappa antagonist norbinaltorphimine. Behav Pharmacol 6:495-504.

Pitts RC, West JP, Hapke DM, Morgan D, Dykstra LA, Picker MJ (1996a) Opioids and rate of positively reinforced behavior. II. Antagonism by $\beta$-funaltrexamine. Exp Clin Psychopharmacol 4:389-395.

Pitts RC, West JP, Morgan D, Dykstra LA, Picker MJ (1996b) Opioids and rate of positively reinforced behavior: differential antagonism by naltrexone. Behav Pharmacol 7:205-215.

Portoghese PS, Sultana M, Takemori AE (1988) Naltrindole: a highly selective and potent non-peptide delta opioid-receptor antagonist. Eur J Pharmacol 146:185-186.

Porzelius J (1995) Memory for pain after nerve-block injections. Clin J Pain 11:112-120.

Powell KR, Picker MJ, Dykstra LA (1994) Serotonin involvement in the discriminative stimulus effects of mu and kappa opioids in rats. Behav Pharmacol 5:255-264.
Pusakulich RL, Nielson HC (1976) Cue use in state-dependent learning. Physiol Psychol 4:421-428.

Shannon HE, Holtzman SG (1976) Evaluation of the discriminative effects of morphine in rats. J Pharmacol Exp Ther 198:54-65.

Shannon HE, Holtzman SG (1979) Morphine training dose: a determinant of stimulus generalization to narcotic antagonists in the rat. Psychopharmacology (Berl) 61:239-244.

Siegel S, Castellan Jr NJ (1988) Non-parametric statistics for the behavioral sciences. New York: McGraw-Hill.

Tallarida RJ, Murray RB (1987) Manual of pharmacologic calculations, Ed 2. New York: Springer.

Teal JJ, Holtzman SG (1980) Discriminative stimulus effects of cyclazocine in the rat. J Pharmacol Exp Ther 212:368-376.

Tilson H, Rech RH, Stolman S (1973) Hyperalgesia during withdrawal as a means of measuring the degree of dependence in morphine dependent rats. Psychopharmacologia 28:287-300.

Traynor JR (1996) The $\mu$-opioid receptor. Pain Rev 3:221-248.

Traynor JR, Nahorski SR (1995) Modulation by $\mu$-opioid agonists of guanosine-5'-O-(3-[ $\left.{ }^{35} \mathrm{~S}\right]$ thio)triphosphate binding to membranes from human neuroblastoma SH-SY5Y cells. Mol Pharmacol 47:848-854.

van den Hoogen RHWM, Colpaert FC (1987) Epidural and subcutaneous morphine, meperidine (pethidine), fentanyl and sufentanil in the rat: analgesia and other in vivo pharmacological effects. Anesthesiology 66:186-194.

Von Voigtlander PF, Lahti RA, Ludens JH (1983) U-50,488: a selective and structurally novel non-mu (kappa) opioid agonist. J Pharmacol Exp Ther 224:7-12.

Wang L, Gintzler AR (1994) Biomodal opioid regulation of cyclic AMP formation: implications for positive and negative coupling of opiate receptors to adenylyl cyclase. J Neurochem 63:1726-1730.

Willner P (1985) In: Depression: a psychobiological synthesis. New York: Wiley.

Winer BJ (1971) Statistical principles in experimental design, Ed 2. New York: McGraw-Hill.

Woods JH, Young AM, Herling S (1982) Classification of narcotics on the basis of their reinforcing, discriminative, and antagonist effects in rhesus monkeys. Fed Proc 41:221-227.

Young AM, Masaki MA, Geula C (1992) Discriminative stimulus effects of morphine: effects of training dose on agonist and antagonist effects of mu opioids. J Pharmacol Exp Ther 261:246-257.

Zukin SR, Brady KT, Slifer BL, Balster RL (1984) Behavioral and biochemical stereoselectivity of sigma opiate/PCP receptors. Brain Res 294:174-177. 